\title{
Assessment of Mass Flows and Fuel Quality During Mechanical Dehydration of Silages Using Near Infrared Reflectance Spectroscopy
}

\author{
Daniela Perbandt • Jürgen Reulein - Felix Richter • \\ Reinhold Stülpnagel • Michael Wachendorf
}

Published online: 17 November 2009

(C) Springer Science + Business Media, LLC. 2009

\begin{abstract}
This study was implemented to evaluate the potential of near-infrared reflectance spectroscopy (NIRS) technology to estimate chemical composition of dried press cake samples characterised by a wide range of parent materials. A total of 210 samples, derived from two studies on production of solid fuels from agricultural crops by application of the IFBB technology (Integrated production of solid fuels and biogas from biomass), were analysed to determine their chemical composition. A Foss XDSspectrometer was used to obtain near-infrared spectra (400-2,500 nm). Prediction equations, developed for chemical components, showed that NIRS technology could predict $\mathrm{N}$, inorganic ash (ash), crude fiber (CF), ether extract (EE) and nitrogen free extracts (NFE) accurately RSQ $_{\text {cal }}$ and SECV of 0.93 and $0.04 \% \mathrm{DM}, 0.89$ and $0.48 \%$ DM, 0.93 and $1.67 \% \mathrm{DM}, 0.87$ and $0.28 \% \mathrm{DM}$ and 0.93 and $1.72 \% \mathrm{DM}$, respectively). Mineral components could also be predicted with a moderate degree of accuracy using NIRS technology $\left(\mathrm{RSQ}_{\mathrm{cal}}\right.$ and SECV of 0.85 and $0.10 \% \mathrm{DM}(\mathrm{K}), 0.77$ and $0.01 \% \mathrm{DM}(\mathrm{P})$ and 0.84 and $0.02 \% \mathrm{DM}(\mathrm{Cl})$, respectively), whereas calibration of gross energy (GE) did not succeed. Subsequent, external validation confirmed these results. Regression of mass flows with measured and NIRS-predicted values showed accurate results (RSQ 0.72-0.99) and promise an accelerated quality management in working biogas plants.
\end{abstract}

D. Perbandt $\cdot$ J. Reulein $\cdot$ F. Richter $\cdot$ R. Stülpnagel $\cdot$

M. Wachendorf $(\triangle)$

Department of Grassland Science and Renewable Plant

Resources, University of Kassel,

37213 Witzenhausen, Germany

e-mail: mwach@uni-kassel.de
Keywords Combustion · IFBB-system · Mineral composition $\cdot$ NIRS $\cdot$ Solid fuels

\section{Introduction}

Most common conversion techniques, i.e. anaerobic fermentation of silages or combustion of hay, straw and other herbaceous biofuels, have a limited conversion efficiency and face important technical limitations. In the case of biogas production, these are associated with the lignocellulose content of the biomass which is resistant to anaerobic fermentation and which inhibits digestion of readily fermentable compounds through their inclusion. Yields of methane decrease [40, 1] and digestion times in the digester increase [29, 22] with decreasing digestibility of substrates. As a consequence, conversion efficiencies of biogas plants based on silages often are low [34, 21]. In order to achieve satisfactory conversion efficiencies waste heat from combined heat and power plants (CHP) must be used which accounts for $2 / 3$ of the total energy contained in the biogas [17]. There is no exact data, but nearly all German biogas plants use the waste heat. It is estimated that the proportion varies between 5 and $100 \%$ of the total heat available and on average less than $20 \%$ of the total heat is used for heating or drying purposes in German biogas plants. A major problem in rural areas is that there is little demand for industrialised heat compared to urban areas.

As for combustion of arable crops, straw and hay, a major limitation lies in the increased dependency on weather conditions for achieving dry matter (DM) contents of $850 \mathrm{~g} / \mathrm{kg}$ [20]. Such DM contents are necessary to prevent microbial deterioration during storage. Compared to wood as the most common solid biofuel, herbaceous biomass contains more nitrogen $(\mathrm{N})$, potassium $(\mathrm{K})$ and chlorine $(\mathrm{Cl})$. During 
combustion $\mathrm{N}$ is almost completely transformed into nitrogen oxides (NOx) which are major air pollutants [18]. Potassium and $\mathrm{Cl}$ are significantly involved in corrosion processes in the furnace, and $\mathrm{K}$ promotes the melting of ash at low temperatures [20]. While ash from wood melts at temperatures above $1,200^{\circ} \mathrm{C}$, ash from hay melts at temperatures below $1,000^{\circ} \mathrm{C}$ [20]. Melting of ash leads to slagging and fouling processes inside the combustion chamber, which reduces the efficiency of the processing plant and its life [31].

IFBB - Integrated Generation of Solid Fuel and Biogas from Biomass

With the aim of overcoming these problems, the Integrated Generation of Solid Fuel and Biogas from Biomass System was proposed [47] which separates ensiled herbaceous biomass by a mechanical dehydration and results in a press liquid rich in easily degradable organic matter and a press solid consisting mainly of fibrous plant parts (Fig. 1). The first step is a hydrothermal conditioning in which silage is mixed with water or other mash fluids (e.g. press fluid) and heated for a short time to macerate cell walls. This treatment produces a mash which is then mechanically dehydrated by a screw press. As an effect of conditioning and dehydration, several minerals (e.g. $\mathrm{K}, \mathrm{Mg}$ and $\mathrm{Cl}$ ) and organic compounds (e.g. water soluble carbohydrates, proteins and lipids) are transferred into the press fluid. Data from dehydration of whole-crop silages of maize, wheat and semi-natural grassland show that press fluids make an excellent substrate for anaerobic digestion with methane yields of up to 500 normal litre (NL) $\mathrm{CH}_{4} \mathrm{~kg}^{-1}$ volatile solids and almost total degradation of organic matter in less than 15 days $[37,17]$. Digester residue is an excellent liquid fertiliser with high concentrations of readily available nutrients. The biogas plant is easily charged and

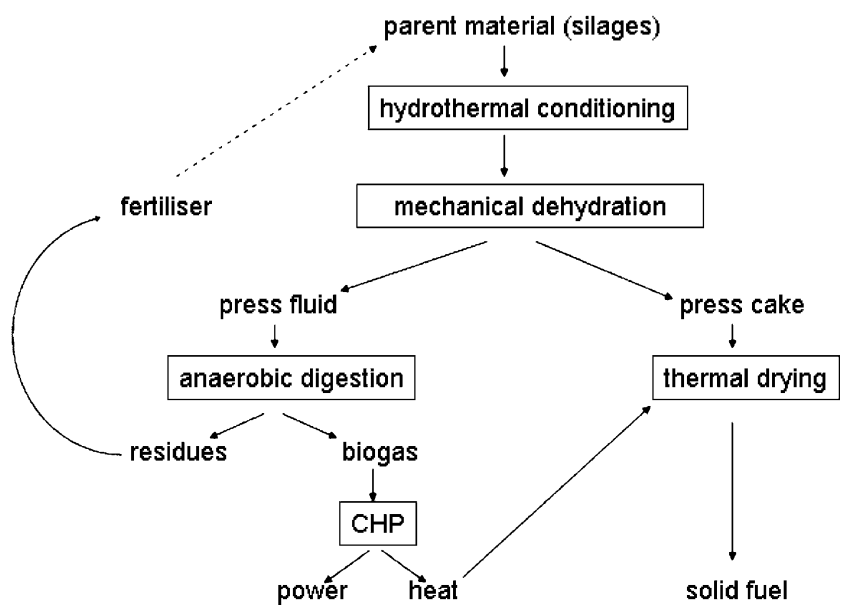

Fig. 1 Flow chart of the IFBB (Integrated Generation of Solid Fuel and Biogas from Biomass) procedure. CHP refers to a combined heat and power plant discharged and no stirring of digester fluid is necessary. The remaining press cake is rich in fibrous constituents and contains relatively low proportions of detrimental minerals, which increase the quality of the resulting biofuel $[47,17]$. With the need to dry the press cake from about $450-500 \mathrm{~g} / \mathrm{kg}$ to $850 \mathrm{~g} / \mathrm{kg} \mathrm{DM}$, the IFBB technology provides a year-round demand for heat produced in the CHP [47]. For arable crops, Graß et al. [17] calculated that approximately $50 \%$ to $60 \%$ of the gross energy contained in the crop is converted to electricity and heat (which is stored in the solid fuel). For semi-natural grassland, with a delayed cut and crude fibre contents well beyond $25 \%$ of DM, conversion efficiencies were in the same range [47].

\section{Focus of This Study}

For technical application it is important to evaluate the process in all stages in time. For example, estimation of mass flows allows the calculation of the amount of nutrients to be recycled to the field, as well as the quantification of methane production from anaerobic digestion. This in turn allows estimation of the amount of heat from the combustion of biogas in the CHP, which is used for thermal drying of the press cake from approximately $40 \%$ to $85 \%$ of DM [47]. On the other hand, value of solid biofuels for combustion depends primarily on the gross energy value and on concentration of nitrogen and minerals detrimental to combustion. However, wet chemical analysis is expensive and time intensive. A widely used and promising technique in agricultural quality management is near-infrared spectroscopy (NIRS) [28, 43]. It is well known that total nitrogen $(\mathrm{N})$, inorganic ash (ash), crude fibre (CF), ether extract (EE) and nitrogen free extracts (NFE) can be determined with NIRS (e.g. [32, 45] as well as mineral compositions [38, 33, 16]. However, most studies concentrate on pure sample sets of wheat [25], maize silage [11, 23], herbages, grass silages $[30,2]$, legumes [19, 9], rice [48] sunflower [26] or hemp [44]. Reliability of NIRS had been questioned when analysis was performed across different plant species and cultivars $[14,39]$. Moreover, there is a lack of knowledge of how much the dehydration and removal of easily mobilized organic and mineral constituents alters the spectral signature of biomass, affecting the relationship between NIR spectra and concentration of various constituents. The present study aims to develop a cheap and fast procedure to evaluate the potential of an energetic conversion of herbaceous crops with the IFBB technique. This includes

- exploration of the potential and accuracy of NIRS for examining quality properties of a heterogeneous set of press cakes from mechanically dehydrated silages, focusing on concentration of major constituents relevant for combustion 
- assessment of mass flows of major organic and mineral constituents during mechanical separation, based on NIR-predicted values.

\section{Material and Methods}

\section{Samples}

A total of 210 press cakes from mechanically dehydrated silages were available for calibration. 187 samples derived from four experiments on arable land in Northern Germany. The samples were harvested from 2002 to 2004, chopped and ensiled in 601 gas-proof polyethylene containers for a minimum of 28 days. In order to enhance the discharging of detrimental constituents 147 silages were conditioned prior to mechanical dehydration with different fluids (i.e. water, press fluid, digester fluid) of different temperatures $\left(5^{\circ} \mathrm{C}\right.$, $60^{\circ} \mathrm{C}, 80^{\circ} \mathrm{C}$, and $100^{\circ} \mathrm{C}$, respectively) in a modified concrete mixer with a volume of $200 \mathrm{~L}$, resulting in a mash with a silage:liquid ratios between 1:1 and 1:6. The mash was kept at a constant temperature with gas burners and stirred for $15 \mathrm{~min}$ in order to thoroughly rinse the silage with water. Dehydration of the silages was carried out using a screw press (type Av; anhydro Ltd., Kassel, Germany). Pressing was conducted with a conical pressing screw and a screen perforation of $1.5 \mathrm{~mm}$ in diameter. The screw was at a pitch of 1:7.5 and rotated with 12 revolutions per minute. Press cakes were composed of the following species: maize (Zea mays), winter wheat (Triticum aestivum), canola (Brassica napus), winter rye (Secale cereale) and winter pea (Pisum sativum), as well as mixed silages of maize/ sunflower (Helianthus), maize/barley straw (Hordeum vulgare), wheat/barley straw, winter pea/rye and winter vetch (Vicia villosa) [36]. Twenty three press cakes derived from semi-natural grassland sites in Central and Southern Germany, representing typical European montane areas with two different poor oat-grass meadows (Arrhenaterion), a small sedge poor-fen meadow (Caricion fuscae), a tall herb vegetation meadow (Filipendulion ulmariae) and a montane hay meadow (Polygono-Tristion). Due to the late harvest date in mid August, most species had finished flowering. The material was collected in 2006, conditioned with water (silage:liquid ratio 1:4) and mechanically dehydrated with the same screw press, described above. Details of the experimental setup can be found elsewhere [47].

\section{Reference Analysis}

Press cakes were dried at $60^{\circ} \mathrm{C}$ for a minimum of three days. Subsequently, N (calculated by CP/6.25), ash, CF, EE and NFE as well as potassium $(\mathrm{K})$, chlorine $(\mathrm{Cl})$ and phosphorus (P) were determined according to Naumann and Bassler [27]. In this study, we refer to $\mathrm{N}$ rather than $\mathrm{CP}$ due to the importance of nitrogen as an air pollutant in combustion processes.

Gross energy values (GE) were calculated for each press cake according to [15]:

$$
\begin{aligned}
\mathrm{GE}[\mathrm{kJ} / \mathrm{kg}]= & 23.9^{*} \mathrm{CP}[\mathrm{g} / \mathrm{kg}]+39.8^{*} \mathrm{EE}[\mathrm{g} / \mathrm{kg}] \\
& +20.1 * \mathrm{CF}[\mathrm{g} / \mathrm{kg}]+17.5^{*} \mathrm{NFE}[\mathrm{g} / \mathrm{kg}]
\end{aligned}
$$

\section{Mass Flow Calculations}

Assessment of mass flow values for specific chemical constituents is essential to evaluate the conditioning and dewatering procedure, as well as to calculate methane yields and corresponding heat from anaerobic fermentation of press fluids, and hence, to evaluate the IFBB-System. Mass flow (MF) of the constituents N, ash, CF, EE, NFE, $\mathrm{K}, \mathrm{Cl}$ and $\mathrm{P}$ (represented by $\mathrm{Z} ; \mathrm{g} / \mathrm{kg} \mathrm{DM}$ ) from the parent material (PM) into the press fluid (PF) and the press cake (PC) were determined according to:

$\mathrm{MF}_{-} \mathrm{Z}_{\mathrm{PF}}=\frac{\mathrm{X} \cdot \mathrm{DM}_{\mathrm{PF}} \cdot \mathrm{Z}_{\mathrm{PF}}}{\mathrm{DM}_{\mathrm{PMC}} \cdot \mathrm{Z}_{\mathrm{PMC}}}$

$\mathrm{MP}_{-} \mathrm{Z}_{\mathrm{PC}}=1-\mathrm{MF}_{-} \mathrm{Z}_{\mathrm{PF}}$

where $\mathrm{X}$ is the quantity of the press fluid as a proportion of the parent material after hydrothermal conditioning (PMC), and $\mathrm{DM}_{\mathrm{PF}}$ and $\mathrm{DM}_{\mathrm{PMC}}$ are the amounts of dry matter in the press fluid and parent material after hydrothermal conditioning, respectively. A comprehensive derivation of these equations is given in Wachendorf et al. [47].

\section{NIRS Measurement}

Reflectance spectra of the ground press cake samples (1 mm sieve, cyclotec $^{\circledR}$ sample mill, Foss Tecator AB, Höganäs, Sweden) were obtained using a XDS-spectrometer (Foss NIRSystems, Hillerød, Denmark). Spectra were collected in the visible and near infrared range from 400 to $2,500 \mathrm{~nm}$ with data collection every $2 \mathrm{~nm}$. Each sample was scanned once using a small ring cup, which is a $45 \mathrm{~mm}$ circular capsule with a quartz window. The spectrum of each sample was an average of 25 sub-scans and was recorded as the logarithm of the inverse of the reflectance $(\log (1 / \mathrm{R}))$. Data analysis was conducted using the WinISI software (version 1.63, Foss NIRSystems/ Tecator Infrasoft International, LLC, Silver Spring, MD, USA). Spectral data were reduced by keeping the first of every eight consecutive spectral points [3], resulting in 259 data points per spectra. 
Spectra Pre-Processing

To correct for differences in particle size and in the spectral curvature of the samples standard normal variate and de-trend scatter correction (SNV-D) [4] was performed. Mathematical pre-processing also included 1, 4, 4 and 2, 4, 4 treatments (number of derivative, wavelength gap over which the derivative is calculated and number of data points in a running average smooth, respectively). Derivatives were used to reduce baseline variation and to enhance spectral features [35].

\section{Calibration}

Modified partial least squares [24] (MPLS) method was used to develop calibration equations. Prior to analysis samples were divided into a calibration and a validation subset, where the validation set included $30 \%$ of the total samples randomly chosen for each constituent (Cozzolino and Morón [9, 7] (Table 1). Calibration was done with the remaining samples. Full cross validation was performed on the calibration set. Therefore the calibration set was divided into five and six groups, respectively, depending on the amount of calibration samples. One group was used for predicting while the rest were available for developing the model. The procedure was performed until all samples were used for both model development and prediction. The number of factors giving the lowest final SECV determined the optimal number of terms to be used for the calibration and hence avoided an overfitting due to too many factors [16], which reduces the validation performance. Two outlier elimination passes were conducted, removing $\mathrm{T}$ outliers $(\mathrm{T}>2.5)$, characterized by a large difference between reference and predicted values, and $\mathrm{H}$ outliers $(\mathrm{H}>10)$, i.e. samples whose spectra differed notedly from the mean sample spectrum. Number of outliers was lowest for $\mathrm{K}$ with 3 and highest for EE, where 11 samples were eliminated (Table 3). Accuracy of calibration models was assessed based on standard error of cross validation (SECV) and coefficient of determination for cross validation $\left(\mathrm{RSQ}_{\mathrm{cal}}\right)$.
The best equations, defined by lowest SECV, were used for validation. The above described spectral treatments and calibration techniques were chosen since they are known to give most accurate predictions of a wide range of parameters of dried samples [30].

The same calibration procedure was conducted with the parent material in order to achieve NIR-estimated values for the mass flow calculations, resulting in an averaged $\mathrm{RSQ}_{\mathrm{cal}}$ of 0.90 for all constituents.

\section{Validation}

Prediction accuracy of models was evaluated on the validation subset, using validation $\mathrm{RSQ}_{\text {val }}$, slope (a) and residual predictive value (RPD). Residual predictive value was defined as the ratio of standard deviation of the laboratory results to the standard error of prediction of the independent validation set and demonstrated how well the calibration models performed in predicting the independent reference data [25]. A RPD value greater than three was considered good and a RPD value in the range from 2.5 to 3 was still satisfying for analytical purposes in most of the NIR applications for agricultural products [10].

\section{Results}

NIRS calibration equations were developed for all constituents of the press cakes. Variability in chemical composition due to heterogeneous parent material was considered suitable to develop NIR calibrations (Table 1). Correlation between constituents was found to be highest for $\mathrm{CF}$ and NFE ( $r=-0.93)$ (Table 2). Correlation coefficients for some mineral constituents, comprising ash, $\mathrm{K}, \mathrm{Cl}$ and NFE were in the range of -0.55 (Cl:NFE) and $0.83(\mathrm{Cl}: \mathrm{K})$.

For N, EE, ash, CF, and NFE very good calibration results were produced by NIRS (Table 3), with coefficients of determination of the cross validation $\left(\mathrm{RSQ}_{\mathrm{cal}}\right)$ of 0.87 for EE, 0.89 for ash and 0.93 for CF, NFE and N. Standard

Table 1 Number of reference samples, separated in calibration and validation set and their composition on a dry matter basis

\begin{tabular}{lcrrrrrrrr}
\hline Constituent & $\mathrm{N}^{\mathrm{a}}$ & $\mathrm{EE}^{\mathrm{a}}$ & $\mathrm{ash}^{\mathrm{a}}$ & $\mathrm{CF}^{\mathrm{a}}$ & $\mathrm{NFE}^{\mathrm{a}}$ & $\mathrm{K}^{\mathrm{a}}$ & $\mathrm{P}^{\mathrm{a}}$ & $\mathrm{Cl}^{\mathrm{a}}$ & $\mathrm{GE}^{\mathrm{b}}$ \\
\hline Number of reference samples & 187 & 209 & 187 & 159 & 122 & 177 & 107 & 177 \\
Number of samples for calibration & 131 & 146 & 131 & 110 & 85 & 125 & 76 & 124 & 83 \\
Number of samples for validation & 56 & 63 & 56 & 49 & 37 & 52 & 31 & 53 & 38 \\
minimum & 0.61 & 1.00 & 1.61 & 20.27 & 2.59 & 0.06 & 0.04 & 0.01 & 18068 \\
maximum & 1.89 & 17.40 & 25.49 & 66.48 & 66.84 & 7.35 & 0.54 & 0.96 & 21890 \\
mean & 1.96 & 2.73 & 4.61 & 35.01 & 52.06 & 0.60 & 0.08 & 0.13 & 18773 \\
SD & 0.15 & 1.60 & 2.32 & 6.97 & 8.31 & 0.58 & 0.05 & 0.09 & 387 \\
\hline
\end{tabular}

${ }^{\mathrm{a}} \mathrm{Min}, \mathrm{max}$, mean and SD in \% DM, ${ }^{\mathrm{b}} \mathrm{Min}$, max, mean and $\mathrm{SD}$ in $\mathrm{kJ} / \mathrm{kg} \mathrm{TM}$ 
Table 2 Correlation coefficients (r) among chemical parameters in samples significance level: $n s$ not signif-
icant, $* 0.05, * * 0.01, * * * 0.001$

errors of cross validation (SECV; \% of DM) were low in relation to the range within the population. Selected math treatments were 2,4,4 for N, ash and CF and 1,4,4 for EE and NFE. Subsequent validation with an independent sample set confirmed the good calibration results with $\mathrm{RSQ}_{\mathrm{val}}$ in the range of 0.90 for NFE and 0.95 for ash and slopes between 0.88 (ash) to 1.02 (NFE). All constituents showed high RPD values, affirming the robustness of calibration equations (Table 3, Fig. 2).

Calibration results of $\mathrm{K}, \mathrm{P}$ and $\mathrm{Cl}$ were moderate with low SECV as well as fairly high $\mathrm{RSQ}_{\text {cal }}$ (Table 3). Best equations were achieved with math treatments $1,4,4$ for $\mathrm{P}$ and 2,4,4 for $\mathrm{K}$ and $\mathrm{Cl}$. Potassium also showed good validation results with $\mathrm{RSQ}_{\mathrm{val}}$ of 0.93 , slope of 0.89 and RPD of 3.9. In contrast, $\mathrm{P}$ and $\mathrm{Cl}$ attained poorer validation results with lower $\mathrm{RSQ}_{\mathrm{val}}$ (0.81 and 0.79 , respectively) and RPD (2.2 for both) (Table 3, Fig. 3), which suggest a lack of robustness of these calibration equations.

Calibration of gross energy $(\mathrm{MJ} / \mathrm{kgDM})$, which is an important parameter describing the energy content of solid fuels resulted in $\mathrm{RSQ}_{\text {cal }}$ of 0.77 and $\mathrm{RSQ}_{\mathrm{val}}$ of 0.39 (results not shown) and thus did not reach adequate accuracy of prediction.
A central parameter for evaluating the IFBB procedure is the mass flow of organic and mineral constituents into the press fluid and press cake. Two data sets of mass flows were calculated, one based on laboratory data and one obtained by NIRS estimated values. Subsequently, a regression was conducted with both data sets to evaluate the prediction accuracy of mass flows in an automated quality management. The mineral group $(\mathrm{K}, \mathrm{Cl}$ and $\mathrm{P})$, ash and GE show narrow ranges for mass flows from parent material into press fluid with a minimum value of $13 \%$ for $\mathrm{GE}$, and a maximum of $95 \%$ for $\mathrm{Cl}$ and $\mathrm{K}$, respectively (Table 4). CF, EE and NFE show broad ranges of mass flows with minima between $3 \%$ (EE) and $13 \%$ (NFE) and maxima between $68 \%(\mathrm{CF})$ and $83 \%$ (NFE). The regression resulted in very good prediction accuracies for all constituents (RSQ from 0.89 to 0.99), except of $\mathrm{Cl}$ which shows a somewhat lower accuracy with an RSQ value of 0.72 (Table 4). Although GE could not be predicted well by NIRS both for parent material and press cakes, a close relationship existed between measured and calculated GE mass flows based on good calibration results for organic constituents used for calculation of GE.

Table 3 Calibration and validation statistics for the constituents for press cakes including number of outliers and best math treatment

\begin{tabular}{|c|c|c|c|c|c|c|c|c|}
\hline \multirow[t]{2}{*}{ Constituent } & \multicolumn{5}{|l|}{ Calibration } & \multicolumn{3}{|l|}{ Validation } \\
\hline & Outliers removed & SD & SECV & $\mathrm{RSQ}_{\text {cal }}$ & Math Treatment & SEP (\% DM) & $\mathrm{RSQ}_{\mathrm{val}}$ & RPD (\% DM) \\
\hline $\mathrm{N}$ & 7 & 0.16 & 0.04 & 0.93 & 244 & 0.04 & 0.90 & 3.7 \\
\hline $\mathrm{EE}$ & 11 & 0.78 & 0.28 & 0.87 & 144 & 0.26 & 0.91 & 3.0 \\
\hline ash & 6 & 1.51 & 0.48 & 0.89 & 244 & 0.43 & 0.95 & 4.4 \\
\hline $\mathrm{CF}$ & 7 & 6.53 & 1.67 & 0.93 & 244 & 1.61 & 0.94 & 3.8 \\
\hline NFE & 9 & 6.75 & 1.72 & 0.93 & 144 & 1.28 & 0.97 & 5.6 \\
\hline K & 3 & 0.27 & 0.10 & 0.85 & 244 & 0.07 & 0.93 & 4.0 \\
\hline $\mathrm{P}$ & 6 & 0.02 & 0.01 & 0.77 & 144 & 0.01 & 0.81 & 2.2 \\
\hline $\mathrm{Cl}$ & 8 & 0.06 & 0.02 & 0.84 & 244 & 0.03 & 0.79 & 2.2 \\
\hline
\end{tabular}

$S D$ standard deviation, $S E C V$ standard error of cross validation, $R S Q_{c a l}$ coefficient of determination of the cross validation, math treatment the first number is the order of the derivative function, the second number is the segment length in data points over which the derivative was taken, the third is the segment length over which the function is smoothed, $S E P$ standard error of prediction, $R S Q_{v a l}$ coefficient of determination of the independent validation, $R P D$ ratio of SD and SEP 
Fig. 2 NIR-predicted versus measured values for CF, NFE, $\mathrm{EE}$ and ash (all values \%DM;

$\boldsymbol{\nabla}=$ maize; $\times=$ maize + straw;

$\boldsymbol{\Delta}=$ maize + sunflower;

$\nabla=$ vech + rye $; \cdot=$ wheat $; \mathbf{m}=$ wheat + straw; $\bigcirc=$ rapeseed; $\square=$ grassland). Lines indicate $1: 1$
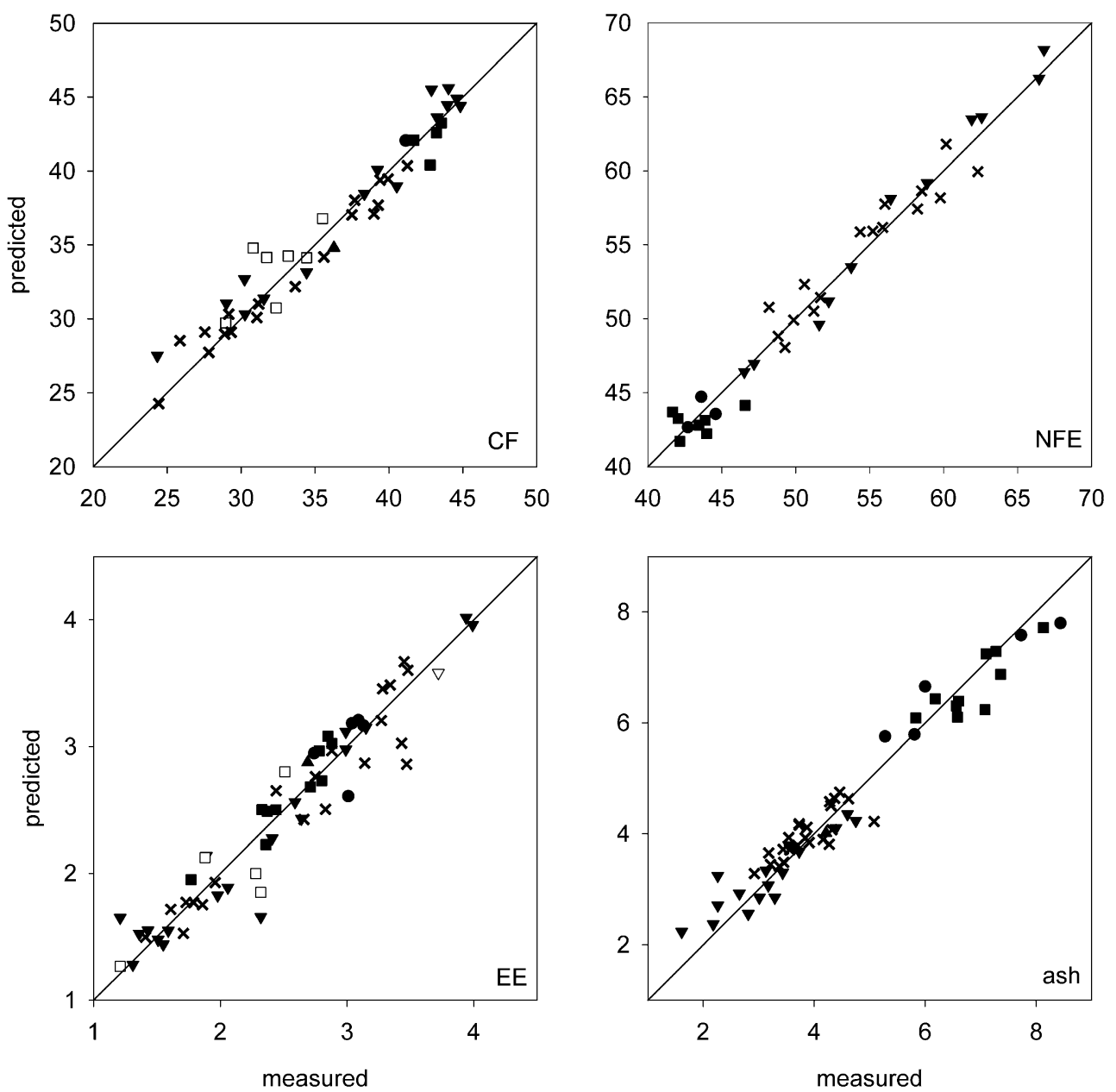

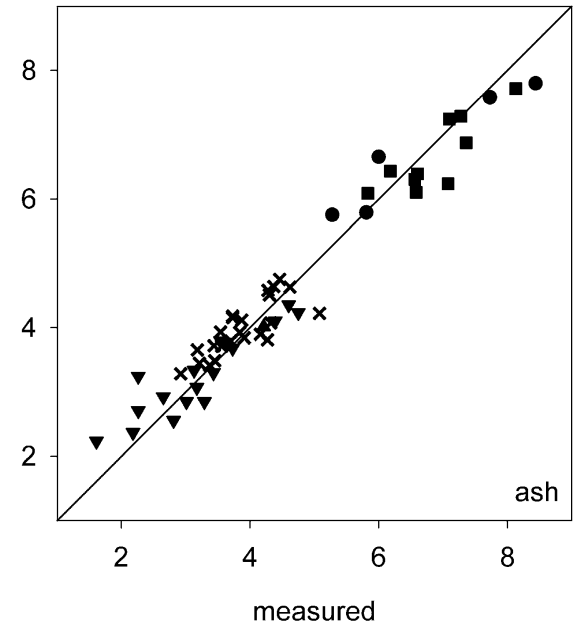

\section{Discussion}

Prediction Accuracy for Solid Fuel Constituents

High correlations among the constituents found in this study were in line with other studies $[12,32]$ and were ascribed to the interrelation of lignin, hemicellulose and cellulose during the analytical extraction process and minerals which were chelated, or closely bound to organic compounds.

The calibration results for all constituents were similar to former studies dealing with dried samples of various crops, usually without ensiling or any pre-treatment. Cozzolino et al. [10] reported $\mathrm{RSQ}_{\mathrm{cal}}$ of 0.91 and a RPD factor of 4.8 for the prediction of N, whereas Valdés et al. [45] and Morón et al. [25] obtained better RSQ values (0.97) and RPD factors (3.9 and 8.5, respectively). For the prediction of crude lipid Berardo et al. [5] found satisfying results in dried pigeon peas with SEC of 2.5 and RSQ of 0.97, whereas DeBoever et al. [12] reported poor calibration results in grass silages (accounted variance of $57.3 \%$, SEP of $5 \mathrm{~g} / \mathrm{kg}$ and SD/SEP of 1.5). The authors ascribe their poor results to systematic errors arising from different residual moisture contents and a small number of calibration samples as well as to the heterogeneous nature of crude lipid in grass silages. The same study obtained good results for ash, as did Park et al. [32], who had similar results with a coefficient of determination of the cross validation $\left(\mathrm{R}_{\mathrm{cv}}^{2}\right)$ of 0.87 and $\mathrm{SD} / \mathrm{SECV}$ of 2.83 . The results for crude fibre in the present study are comparable with results achieved by DeBoever et al. $[12,13]$ in grass and maize silages. By contrast, Xiccato et al. [49] reported poor prediction accuracy of crude fibre with $\mathrm{R}^{2}$ of 0.60 and SEP of $16 \mathrm{~g} / \mathrm{kg}$. The results for nitrogen free extracts (NFE) were similar to those reported by Castrillo et al. [8] but showed, regarding the RPD values, a markedly higher robustness.

Ruano-Ramos et al. [38] achieved slightly better results regarding $\mathrm{K}$ and $\mathrm{P}$ for sample sets of semi-arid grasslands with a $\mathrm{R}^{2}$ of 0.92 and 0.88 as well as a SEC of 1.76 and 0.22 , respectively, using $\log 1 / \mathrm{R}$ calibrations. Halgerson et al. [19] investigated alfalfa stems and leafs and achieved better results for $\mathrm{K}\left(\mathrm{R}^{2}\right.$ of 0.95 ; SEC of 1090) in oven-dried alfalfa stems and for $\mathrm{P}\left(\mathrm{R}^{2}\right.$ of 0.91 ; SEC of 150$)$ in suncured alfalfa leaves. The examination of ground alfalfa samples yielded in a $\mathrm{R}^{2}$ of 0.89 (SEC of 1180) and 0.90 (SEC of 244) for K and P, respectively, as reported by González-Martín et al. [16]. Residual predictive value (RPD) factors reported by the same authors were similar 
Fig. 3 NIR-predicted versus measured values for $\mathrm{K}, \mathrm{Cl}, \mathrm{P}$ and $\mathrm{N}$ (all values $\% \mathrm{DM} ; \boldsymbol{\nabla}=$ maize; $x=$ maize + straw; $\boldsymbol{\Delta}=$ maize + sunflower; $\nabla=$ vech + rye; $\bullet=$ wheat; $\mathbf{\square}=$ wheat + straw; $\mathrm{o}=$ rapeseed; $\square=$ grassland). Lines indicate 1:1
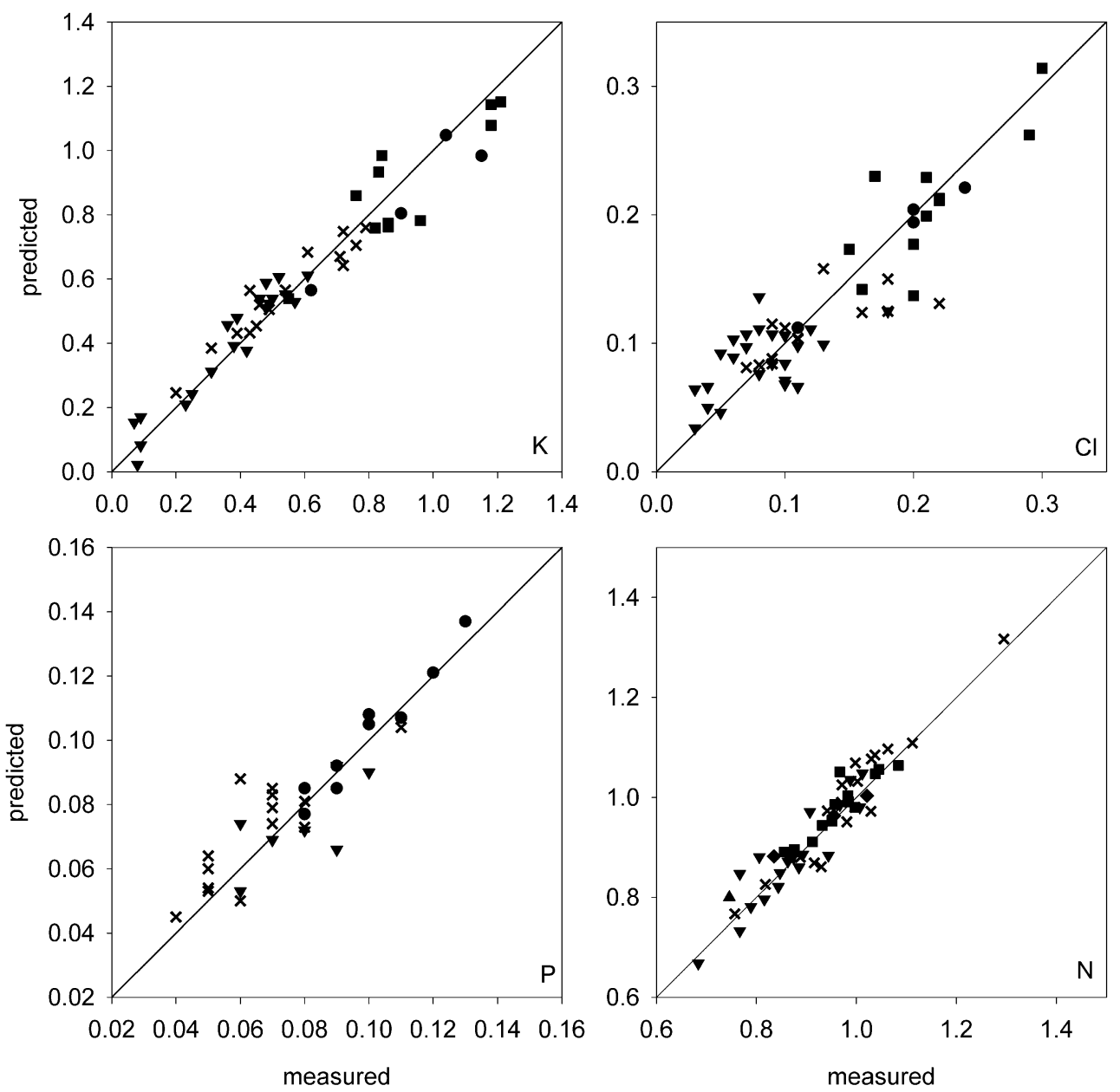

to those achieved in the present study for K (3.4) but much better for $\mathrm{P}$ (3.6). However, low accuracies of $\mathrm{P}$ estimation were found by Petisco et al. [33] using an external validation set and RPD factors.

Table 4 Statistics for mass flows, based on measured values, and coefficient of determination (RSQ) of the relationship between measured and NIR-estimated mass flows from the parent material into the press fluid

\begin{tabular}{lccccc}
\hline Constituent & $\mathrm{n}$ & $\min (\%)$ & $\max (\%)$ & mean (\%) & RSQ \\
\hline $\mathrm{N}$ & 26 & 22 & 68 & 52 & 0.94 \\
ash & 28 & 32 & 87 & 51 & 0.89 \\
$\mathrm{CF}$ & 18 & 5 & 68 & 23 & 0.97 \\
$\mathrm{EE}$ & 28 & 3 & 83 & 31 & 0.92 \\
$\mathrm{NFE}$ & 20 & 13 & 82 & 34 & 0.98 \\
$\mathrm{Cl}$ & 23 & 32 & 95 & 64 & 0.72 \\
$\mathrm{~K}$ & 19 & 33 & 95 & 72 & 0.91 \\
$\mathrm{P}$ & 10 & 44 & 85 & 67 & 0.97 \\
$\mathrm{GE}$ & 23 & 13 & 49 & 27 & 0.99 \\
\hline
\end{tabular}

$n$ number of samples used for regression, $\min$ minimum, $\max$ maximum
Only one study could be found reporting calibration results for chlorine in oven dried alfalfa stems [19] with a coefficient of determination of the cross validation $\left(\mathrm{R}_{\mathrm{cv}}^{2}\right)$ of 0.84 , which are in line with our results. However, the validation with independent samples of press cakes showed a lack of accuracy for $\mathrm{Cl}$ estimation. These results may be related to the difficulty of estimating mineral concentrations by NIRS. Cozzolino and Morón [9] quoted that SEC and $\mathrm{R}^{2}$ cal were inappropriate indicators for mineral determination, because the NIRS was not directly measuring the element, but the organic compound the element was related to $[32,16]$ or through its association with hydrated inorganic molecules. According to Cozzolino and Morón [9], $\mathrm{R}^{2}$ values in mineral determination are governed more by the amount or variability (range in concentration) present than by a direct relationship between variation in concentration and absorption in the NIR region.

Reasons for the low prediction accuracy of GE may be the narrow range of values (Table 1) which is in line with data from previous experiments [42] as well as the error inherent to the regression equation used to calculate gross energy (see Eq. 1). Furthermore, unlike energy values used in feed evaluation systems (e.g. net energy lactation, NEL) 
which are strongly related to fibrous constituents and usually well-predicted by NIRS [46] gross energy is a complex parameter which is affected by all organic constituents of the fuel. Thus, albeit prediction accuracy by NIRS was unsatisfactory the calculated gross energy values may be plausible, which is suggested by the conformity with calorimetric data from various crops in a previous study [41].

\section{Assessment of Fuel Quality}

To evaluate the combustion quality of press cakes from herbaceous crops quality values of press cakes were compared with those from common solid biofuels i.e. beechwood, woodchips (willow and poplar) and grains (wheat, rye and triticale) [20], regarding four major constituents (N, K, Cl and GE) (Fig. 4). Although the press cake data show a broad variation, a comparable or better quality than grains, especially for $\mathrm{N}$ and GE, was achieved. However, quality of press cakes was generally inferior to wooden biomasses, indicating the need to adapt the combustion appliance to inferior feedstocks.

\section{Evaluation of NIR-Predicted Mass Flows}

The high prediction accuracy for mass flows of organic and mineral constituents in the IFBB procedure is an important outcome of the present study, as it provides a basis for a cheap and accelerated assessment of the operating status of a continuously working plant. However, the presented NIRS procedure depends on dried and ground material both from parent material and press cake, which prolongs the system response time. The use of field spectroscopy may provide perspectives for a further acceleration as recent calibration work showed promising results for major quality parameters of various forage crops [6].

\section{Conclusions}

The NIRS technology has good potential for evaluation of the IFBB process, as it establishes the basis for a cheap and fast assessment of several important parameters in the energetic conversion of herbaceous crops. The results of the present study with a heterogeneous set of press cakes from mechanically dehydrated silages of herbaceous crops show that,

- the concentration of major constituents relevant for combustion can be predicted with satisfactory accuracy. Lowest validation errors were achieved with SEP of $0.01 \%$ DM for P, while SEP of CF was highest with
Fig. 4 Press cakes $(P C)$, beechwood $(B)$, woodchips (willow and poplar; $W C$ ) and grains (wheat, rye and triticale; $G$ ) compared with regard to major quality parameters for combustion chlorine $(\mathrm{Cl})$, potassium $(K)$, nitrogen $(N)$ and gross energy $(G E)$

$1.61 \%$ DM. Fuel quality of press cakes obtained in the study was higher than that from cereal grains, but lower than that from wooden biomasses.

- mass flows of major organic and mineral constituents during mechanical separation based on NIR-predicted values can be assessed with appropriate accuracy (RSQ $0.72-0.99)$. These parameters are major determinants of the operating status and constitute a prerequisite for an effective system control.

\section{References}

1. Amon T, Amon B et al (2007) Biogas production from maize and dairy cattle manure - influence of biomass composition on the methane yield. Agric Ecosyst Environ 118:173-182

2. Andrés S, Giráldez FJ et al (2005) Nutritive evaluation of herbage from permanent meadows by near-infrared reflectance spectroscopy: 1. Prediction of chemical composition and in vitro digestibility. J Sci Food Agric 85:1564-1571

3. Azzouz T, Puigdoménech A et al (2003) Comparison between different data pre-treatment methods in the analysis of forage samples using near-infrared diffuse reflectance spectroscopy and partial least-squares multivariate calibration method. Anal Chim Acta 484:121-134

4. Barnes RJ, Dhanoa MS, Lister SJ (1989) Standard normal variate transformation and de-trending of near-infrared diffuse reflectance spectra. Appl Spectrosc 43(5):772-777

5. Berardo N, Dzowela BH et al (1997) Near infrared calibration of chemical constituents of Cajanus cajan (pigeon pea) used as forage. Anim Feed Sci Technol 69:201-206

6. Biewer S, Fricke T, Wachendorf M (2009) Development of canopy reflectance models to predict forage quality of legumegrass mixtures. Crop Sci 49:1917-1926

7. Brunet D, Barthès BG et al (2007) Determination of carbon and nitrogen contents in Alfisols, Oxisols and Ultisols from Africa and Brazil using NIRS analysis: effects of sample grinding and set heterogeneity. Geoderma 139:106-117

8. Castrillo C, Baucells M et al (2005) Energy evaluation of extruded compound foods for dogs by near-infrared spectroscopy. J Anim Physiol Anim Nutr 89:194-198

9. Cozzolino D, Morón A (2004) Exploring the use of near infrared reflectance spectroscopy (NIRS) to predict trace minerals in legumes. Anim Feed Sci Technol 111:161-173

10. Cozzolino D, Fassio A et al (2006) Measurement of chemical composition in wet whole maize silage by visible and near infrared reflectance spectroscopy. Anim Feed Sci Technol 116:329-336

11. Deaville ER, Givens DI (1998) Regions of normalised near infrared reflectance difference spectra related to the rumen degradation of fresh grass, grass silage and maize silage. Anim Feed Sci Technol 72:41-51

12. DeBoever JL, Cottyn BG et al (1996) Prediction of the feeding value of grass silages by chemical parameters, in vitro digestibility and near-infrared reflectance spectroscopy. Anim Feed Sci Technol 60:103-115

13. DeBoever JL, Cottyn BG et al (1997) Prediction of the feeding value of maize silages by chemical parameters, in vitro digestibility and NIRS. Anim Feed Sci Technol 66:211-222

14. Foley WJ, Mcllwee A et al (1998) Ecological applications of near infrared reflectance spectroscopy - a tool for rapid, cost-effective prediction of the composition of plant and animal tissues and aspects of animal performance. Oecologia 116:293-305
15. Gesellschaft für Ernährungsphysiologie (GfE) (1995) Energieund Nährstoffbedarf landwirtschaftlicher Nutztiere Nr. 6. Empfehlungen zur Energie- und Nährstoffversorgung der Mastrinder (Energy and nutritional requirement of agricultural livestock No 6 Recommendations for energy and nutrient supplies of feeder cattle). DLG-Verlag, Frankfurt a.M.

16. González-Martín I, Hernández-Hierro JM, González-Cabrera JM (2007) Use of NIRS technology with a remote reflectance fibreoptic probe for predicting mineral composition $(\mathrm{Ca}, \mathrm{K}, \mathrm{P}, \mathrm{Fe}, \mathrm{Mn}$, $\mathrm{Na}, \mathrm{Zn}$ ), protein and moisture in alfalfa. Anal Bioanal Chem 387:2199-2205

17. Graß R, Reulein J et al (2009) Die integrierte Biogas- und Festbrennstofferzeugung aus Ganzpflanzensilagen (Integrated biogas and solid fuel production from whole-crop silage). Berichte Landwirtschaft 87:43-64

18. Greul U (1998) VDI-Fortschrittsberichte, Reihe 6: Energietechnik, Nr. 388, Experimentelle Untersuchung feuerungstechnischer NOx-Minderungsverfahren bei der Kohlenstaubverbrennung (VDI Progress reports, series 6: Energy technique, Nr. 388, Experimental investigation on NOx mitigation techniques for the combustion of carbon dust), Düsseldorf, Germany: VDI-Verlag

19. Halgerson JL, Sheaffer CC et al (2004) Near-infrared reflectance spectroscopy prediction of leaf and mineral concentrations in Alfalfa. Agron J 96:344-351

20. Hartmann H (2001) Brennstoffzusammensetzung und-eigenschaften (Composition and characteristics of fuels). In: Kaltschmitt M, Hartmann H (eds) Energie aus Biomasse: Grundlagen. Techniken und Verfahren. Springer-Verlag, Berlin, Heidelberg, New York, pp $248-272$

21. Herrmann C, Heiermann M et al (2007) Parameters influencing substrate quality and biogas yield. In: Proceedings of the 15th European Biomass Conference and Exhibition, Berlin, Germany, 2007, pp 809-819. Florence, Italy, ETA-Renewable Energies

22. Lemmer A, Oechsner H (2001) Co-fermentation of grass and forage maize. Landtechnik 56:412-413

23. Lovett DK, Deaville ER et al (2004) Using near infrared reflectance spectroscopy (NIRS) to predict the biological parameters of maize silage. Anim Feed Sci Technol 115:179-187

24. Martens H, Naes T (1989) Multivariate Calibration. Wiley, Chichester, p 419

25. Morón A, García A et al (2007) Preliminary study on the use of near-infrared reflectance spectroscopy to assess nitrogen content of undried wheat plants. J Sci Food Agric 87:147-152

26. Moschner CR, Biskupek-Korell B (2006) Estimating the content of free fatty acids in high-oleic sunflower seeds by near-infrared spectroscopy. Eur J Lipid Sci Technol 108:606-613

27. Naumann C, Bassler R (2004) Methodenbuch Band III Chemische Untersuchungen von Futtermitteln (Book of methods volume III: Chemical analysis of animal feeds). Verband Deutscher Landwirtschaftlicher Untersuchungs- und Forschungsanstalten, 5th edn. VDLUFA-Verlag, Darmstadt

28. Norris KH, Barnes RF et al (1976) Predicting forage quality by near-infrared reflectance spectroscopy. J Anim Sci 43:889-897

29. Noike T, Endo G et al (1985) Characteristics of carbohydrate degradation and the rate-limiting step in anaerobic digestion. Biotechnol Bioeng 27:1482-1489

30. Nousiainen J, Ahvenjärvi S et al (2004) Prediction of indigestible cell wall fraction of grass silage by near infrared reflectance spectroscopy. Anim Feed Sci Technol 115:295-311

31. Obernberger I, Brunner T, Bärnthaler G (2006) Chemical properties of solid biofuels - significance and impact. Biomass Bioenergy 30:973-982

32. Park RS, Agnew RE et al (1998) The use of near infrared reflectance spectroscopy (NIRS) on undried samples of grass silage to predict chemical composition and digestibility parameters. Anim Feed Sci Technol 72:155-167 
33. Petisco C, García-Criado B et al (2005) Use of near-infrared reflectance spectroscopy in predicting nitrogen, phosphorus and calcium contents in heterogeneous woody plant species. Anal Bioanal Chem 382:458-465

34. Prochnow A, Heiermann M et al (2005) Seasonal pattern of biomethanisation of grass from landscape management. In: Agricultural Engineering International: the CIGR E-journal, Vol. VII, Manuscript EE 05 011, http://cigrjournal.org/index.php/ Ejournal (accessed 2 January 2009)

35. Reeves J, McCarty G, Mimmo T (2002) The potential of diffuse reflectance spectroscopy for the determination of carbon inventories in soils. Environ Pollut 116:S277-S284

36. Reulein J, Scheffer K, Stülpnagel R et al (2007) Efficient utilization of biomass through mechanical dehydration of silages. In: Proceedings of the 15th European Biomass Conference \& Exhibition, Germany, pp 1770-1774

37. Richter F, Graß R et al (2009) Utilization of semi-natural grassland through integrated generation of solid fuel and biogas from biomass. II. Effects of hydrothermal conditioning and mechanical dehydration on anaerobic digestion of press fluids. Grass and Forage Science (in press)

38. Ruano-Ramos A, García-Ciudad A, García-Criado B (1999) Near infrared spectroscopy prediction of mineral content in botanical fractions from semi-arid grasslands. Anim Feed Sci Technol 77:331-343

39. Ruano-Ramos A, García-Ciudad A, García-Criado B (1999) Determination of nitrogen and ash contents in total herbage and botanical components of grassland systems with near infra-red spectroscopy. J Sci Food Agric 79:137-143

40. Shiralipour A, Smith PH (1984) Conversion of biomass into methane gas. Biomass 6:85-92

41. Stülpnagel R, Behringer T et al (1992) Investigations for a cheap estimation of the net calorific values (n.c.v.) of different biomasses. 7th European Conference on Biomass for Energy and Environment, Agriculture and Industry, Florence, Italy

42. Stülpnagel R, Wiest W, Klose W, Wachendorf M (2008) Fortschritte im Bereich der energetischen Wandlung von landwirtschaftlichen Kulturpflanzen durch erweiterte Analytik des Erntegutes (Progress in the area of energetic conversion of agricultural crops by enhanced analysis of the harvest). In: DGMK-Fachtagung Energetische Nutzung von Biomassen, pp 199-206, Velen, Germany, 2008

43. Stuth J, Jama A, Tolleson D (2003) Direct and indirect means of predicting forage quality through near infrared reflectance spectroscopy. Field Crops Res 84:45-56

44. Toonen MAJ, Maliepaard C et al (2004) Predicting the chemical composition of fibre and core fraction of hemp (Cannabis sativa L.). Euphytica 140:39-45

45. Valdés C, Andrés S et al (2006) Potential use of visible and near infrared reflectance spectroscopy for the estimation of nitrogen fractions in forages harvested from permanent meadows. J Sci Food Agric 86:308-314

46. Volkers KC, Wachendorf $M$ et al (2003) Prediction of the quality of forage maize by near-infrared reflectance spectroscopy. Anim Feed Sci Technol 109:183-194

47. Wachendorf M, Richter F et al (2009) Utilisation of semi-natural grassland through an integrated generation of solid fuel and biogas from biomass. Part I: Effects of hydrothermic conditioning and mechanical dehydration on mass flows of organic and mineral plant compounds and nutrient balances. Grass Forage Sci 64:132-143

48. Wu JG, Shi C, Zhang X (2002) Estimating the amino acid composition in milled rice by near-infrared reflectance spectroscopy. Field Crops Res 75:1-7

49. Xiccato G, Trocino A, DeBoever JL et al (2003) Prediction of chemical composition, nutritive value and ingredient composition of European compound feeds for rabbits by near infrared reflectance spectroscopy (NIRS). Anim Feed Sci Technol 104:153-168 